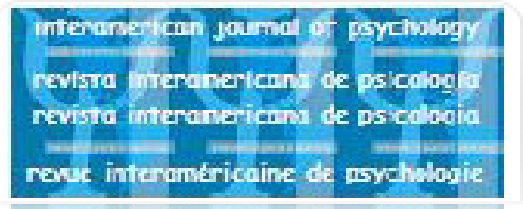

Interamerican Journal of Psychology

ISSN: 0034-9690

rip@ufrgs.br

Sociedad Interamericana de Psicología

Organismo Internacional

Gonzalez, Nelly; Morgan Consoli, Melissa L.

The aftermath of deportation: Effects on the family

Interamerican Journal of Psychology, vol. 46, núm. 3, septiembre-diciembre, 2012, pp. 459-467

Sociedad Interamericana de Psicología

Austin, Organismo Internacional

Available in: http://www.redalyc.org/articulo.oa?id=28425871014

How to cite

Complete issue

- More information about this article

Journal's homepage in redalyc.org

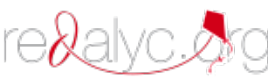

Scientific Information System Network of Scientific Journals from Latin America, the Caribbean, Spain and Portugal Non-profit academic project, developed under the open access initiative 


\title{
The aftermath of deportation: Effects on the family
}

University of California, Santa Barbara

\begin{abstract}
The primary aim of this qualitative study was to understand how Latino/a families in the United States are affected when a family member is deported. The U.S. Census Bureau (2008) reports that $4 \%$ of the population consists of undocumented immigrants and that $47 \%$ of households containing an undocumented immigrant are family households (e.g. have a spouse or child). Given this large number of families liable for experiencing deportation, the need to conduct a study exploring this phenomenon is important. Five individuals who identified as Latino/a and had had a family member deported were interviewed about their experience. Data was analyzed using a phenomenological approach from which five main themes emerged: lifestyle changes and adjustments, social support, impact on family unit, impact on individual family members, and solutions to family separation. These results are discussed as well as possible implications.

Keywords: deportation, immigrants, Latino/a families, phenomenological
\end{abstract}

\section{La Secuela de Deportación: Los Efectos en la Familia Compendio}

\begin{abstract}
La intención de este estudio cualitativo fue el poder comprender cómo las familias Latinas en los Estados Unidos son afectadas cuando un miembro de la familia es deportado. El U.S. Census Bureau reporta que $4 \%$ de la población son inmigrantes indocumentados y que $47 \%$ de las casas con un inmigrante indocumentado son casas de familia (e.g. con esposo/a o hijos). Debido a este numero tan grande de familias en riesgo de tener a un familiar deportado, la necesidad de conducir un estudio explorando este fenómeno parece de suma importancia. Cinco individuos que se identificaron como Latino/a y que tuvieron a un familiar deportado fueron entrevistados. La información fue analizada usando un método fenomenológico. Cinco temas generales surgieron: cambios en estilo de vida, apoyo social, impacto en la familia como unidad, impacto en miembros de la familia, y soluciones para reunificación. Los resultaos son discutidos al igual que posibles implicaciones.

Palabras clave: deportación, inmigrantes, familias Latinas, fenomenológico
\end{abstract}

Latino/as are the fastest growing minority population in the United States of America (U.S.) and it is estimated that by the year 2050 they will account for $29 \%$ of the population, a great increase compared to $14 \%$ in 2005 (Pew Hispanic Center, 2008). California has the largest number of Latino/as in the U.S. with $35.9 \%$ of the population being of Latino/a origin (Pew Hispanic Center, 2006). This rapid growth has been considered a concern by some U.S. citizens, many of whom believe that all immigrants are criminals, individuals who take their jobs, or people who are taking advantage of them by making money but not paying taxes (Buckler, Swatt, \& Salinas, 2009; Lee \& Ottati, 2002), otherwise known

\footnotetext{
${ }^{1}$ Correspondence concerning this article should be directed to the second author at 2107 Education Building, Counseling, Clinical and School Psychology Program, University of California, Santa Barbara. Email: mmorgan@education.ucsb.edu
}

as the "economic threat" or "culture threat" hypotheses. Individuals who believe that Latino/a immigrants are either an economic or cultural threat are likely to support deportation (Buckler, et al., 2009). These beliefs, increased by the $9 / 11$ terrorist attacks, have led to higher border security and have placed enormous focus on creating stricter immigration policies. An example of this growing concern about immigrants is the billions of dollars that are being invested in building larger fences around the southwestern border of the U.S. and the implementation of better immigration technology (The White House, August 12, 2010). Not only are border security measures being reinforced, but in 2003 the U.S. Immigration and Customs Enforcement (ICE) agency was created to focus on enforcing immigration laws such as finding and deporting undocumented immigrants.

Homeland Security reports that there were a total of 358,886 foreign born immigrants deported from the 
U.S. in 2008 and, since 1997, over 1 million families have been divided due to deportation (Human Rights Watch, 2009). This high number of families being separated is alarming due to repercussions that this can have on a family's financial state or emotional well-being. Specifically, deportation can greatly disrupt Latino/a families' familismo. Familismo has been identified as "attitudes, behaviors, and family structures operating within an extended family system" (Coohey, 2001). Several studies have indicated that Latino/as who felt a sense of belonging or support appeared to be more resilient (Clauss-Ehlers \& Wibrowski, 2007; Carranza, 2007) than counterpart Latino/as who have less sense of belonging. Other studies have found familismo to be a source of inspiration during adversity, predict lower school absences, increase academic effort, and to be associated with higher self-esteem and internalizing problems (Smokowski \& Bacallao, 2006; Parra-Cardona, 2006). These findings on familismo are indicative of how important family can be to a Latino/a individual and how feelings of belonging as well as having a strong connection to one's family can be considered important factors in the daily functioning of Latino/as. It has also been found to serve as a protective factor against alcohol consumption (Gil, Wagner, \& Vega, 2000) and other risk-taking behaviors (Bacallao \& Smokowski, 2007), as well as to foster better academic outcomes (Esparza \& Sanchez, 2008) and resilience (Clauss \& Wibrowski, 2007).

Despite its large impact on Latino/a families and U.S. society, there are few studies looking at deportation as a societal phenomenon. Learning more about the outcomes or after effects of deportation on individuals is important in order to: 1) learn more about this growing phenomenon and its repercussions for families and society, 2) be aware of the health needs and inadequate resources that exist in our communities, and 3) gain greater knowledge about Latino/a families who are presented with this type of adversity. By obtaining this information professionals and service providers will be prepared to deal with situations resulting from deportation, but more importantly they will be better informed on how they can aid in ensuring the health and well-being of those affected by this phenomenon. In cases where children are involved, the absence of a parent can be particularly concerning as parents are key in a child's emotional, mental, and physical development (de Minzi, 2009). Therefore, obtaining this information can be particularly helpful so that teachers, counselors and other agencies providing services to children can have a guide on issues to address so that children don't fall behind at school or become affected developmentally. The goal of the current study is to explore the phenomenon of experiencing deportation (i.e. a family member being deported) and its effect on that person's family.

\section{Latino/a Immigrants}

Previous research on Latino/as has concluded that Latino/a immigrants are at risk for a variety of stressors such as discrimination, prejudice, acculturative stress, and limited access to healthcare (Sullivan, 2005; Finch \& Vega, 2003). Yet, Latino immigrant health research has found a health paradox among this population (Caplan, 2007). This health paradox indicates that, despite experiencing often extreme environmental stressors, Latino/a immigrants appear to have better health outcomes (in substance use, mood disorders, nutrition, and infant mortality) when compared to their more acculturated counterparts (Lara, Gamboa, Kahramanian, Morales, \& Bautista, 2005; Ortega, Rosenheck, Alegria, \& Desai, 2000). This paradox has also been found present for mental health outcomes (Baker, 1996, Bender \& Castro, 2000).

One explanation for this paradox is that acculturated immigrants, most commonly immigrants who have lived in the U.S. longer, may have a reduction of family cohesion, and traditional values such as familismo and parental respect (Gil, Wagner, \& Vega, 2000). They might also experience increased isolation from family members that can lead to greater health issues (Caplan, 2007). Studies indicate that cultural factors such as family support and religiosity can be protective factors in the face of this process (Grant, et al., 2004; Smokowski, Rose, \& Bacallao, 2006).

There is little research that directly addresses deportation and its effects on Latino/a families. Therefore, the purpose of this study is to further explore how deportation affects the families of individuals who were deported.

\section{Methods}

\section{Participants}

Participants were recruited from two counties in southern California. Participants were recruited through community contacts that briefly informed them about the research and researcher. Community contacts consisted of a leader from a Latino/a community organization and a leader from a religious institution frequented by Latino/as. The community contact identified potential participants who met study criteria and gave interested participants the researcher's contact information.

Participation criteria required participants to selfidentify as being of Latino/a origin and to be at least 18 -years- old. Participants also needed to identify as having experienced the deportation of a nuclear fam- 
ily member (i.e. parent or sibling). Three women and two men participated and brief descriptions of each participant follow. Pseudonyms are used to maintain the confidentiality of the participants.

Participant 1. Karla is a 56-year-old woman who self-identified as Mexican. Her husband was deported twice 35 years ago but was able to return after a few months and remain permanently in the U.S. by obtaining citizenship. His deportation was the result of having provided false information to the immigration department. At the time of the deportation Karla was living with her two infant children and received support from her mother who lived close by.

Participant 2. Rebecca is a 39-year-old woman who self-identified as Mexican. Her 20-year-old son was deported 4 months before the interview and was able to return after a few months. He was deported after being arrested for a misdemeanor. Her son was living with his girlfriend at the time of the deportation, in the same city as Rebecca. Since his return he has lived with Rebecca and her husband.

Participant 3. Carmen is a 47-year-old woman who self-identified as Mexican and reported that her husband was deported 2 years before the interview. Her husband did not return to the U.S. She remained in the U.S. and lives with her five children, two of which are young adults who help her financially.

Participant 4. Julio is a 24-year-old male who self-identified as Mexican. His mother was deported 3 months before the interview and was able to return within two months. When his mother was deported he was living with his father and two younger siblings.

Participant 5. Jose self-identified as a 23-year-old Peruvian and reported that his father was deported 3 years before the interview with no planned return. During the deportation he was living with his mother and younger sibling. The remaining family moved soon after the deportation to avoid any further immigration issues and they all continue to live together.

\section{Researchers}

The first researcher identifies as a female, MexicanAmerican in a doctoral program in counseling psychology. She is bilingual in Spanish and English. At the time of the study she had experience in both qualitative and quantitative research, over one year of counseling training and experience, and had primarily conducted research on resilience in Latino/as. Interest in this topic was influenced by the stories on families being suddenly and unexpectedly separated due to deportation. Having no personal experiences with deportation, but having heard stories, she did expect that families might have negative experiences after the deportation or that repercussions would be present. In order to recognize the impact of expectations and biases on the interviews and findings, the expectations were written down and explored with her supervisor and an undergraduate student who participated in data analysis at the beginning of the study. While phenomenological research is necessarily subjective, "bracketing" such views ahead of time can serve to facilitate more awareness of where certain interpretations are coming from. Bracketing involves the researcher trying to remove his/her preconceived ideas and interpretations from the analysis of the phenomenon under study (Moustakas, 1994).

The second author is a female Counseling Psychology faculty member who identifies as having both Latina and European heritage. Her research is on resilience and thriving in immigrants and the Latino/a population. She has conducted and supervised many qualitative studies.

The undergraduate male student who participated in the data analysis process self identified as Latino. He is bilingual in Spanish and English. He was a senior who graduated shortly after with his degree in psychology. The student had previously been trained and participated in a consensual qualitative research (CQR) project, and was further trained in phenomenological research in order to aid in this project. He was also interested in conducting research with Latino/a populations and believed that deportation negatively affects families.

\section{Procedures}

The researcher informed the community contact about the study, and asked for assistance in identifying and approaching individuals who might be eligible. Once the community contact identified a potential participant, the researcher contacted the individual and if they were interested, an appointment was scheduled. In two of the cases, the participant was recruited after a community contact e-mailed individuals in her organization's listserv and the participant then contacted the researcher. The e-mail contained information about the purpose of the study, eligibility requirements, and contact information of the researcher.

Once individuals agreed to participate, the researcher went over informed consent and answered any questions participants had about the research. Interviews, which lasted approximately one hour, took take place in a relatively private area where participants felt comfortable, such as on university grounds, in their homes, or at a coffee shop. All participants agreed to be audio-recorded. As a token of appreciation for their participation, participants were given a ten-dollar gift certificate to a local store.

\section{Instruments}

Demographic Questionnaire. Designed for the 
purposes of this study, the questionnaire contains questions about the participant's age, nationality, and income level.

Semi-structured Interview. The semi-structured interview consisted of two general questions about the participant's experience with deportation and possible changes that occurred after the event, as well as follow up questions that were used if necessary for clarification. Four of the interviews were conducted in Spanish and one in English, based on the participant's preference.

\section{Data Analysis}

All interviews were transcribed by the researchers and analyzed following Moustakas' (1994) Transcendental Phenomenology with the van Kaam modification. This qualitative methodology was originally developed by Husserl, a mathematician, and was refined by others including Heidegger and Schutz (Creswell, 1997, p.58). Husserl adopted the idea that the external world relies on how individuals consciously perceive or live in the world. In other words, it is believed that people can only be certain of what is known through consciousness and sensory perception. Therefore, in order to understand a phenomenon, we must understand the subjective experience of people within the phenomenon. This inductive approach is reflective of a constructivist worldview because it relies on the subjective interpretations of participants' experience of a phenomenon and theories or conclusions are shaped from these subjective experiences. In phenomenology, the experiences of participants can be gathered through interviews, observations, journals, or other artistic outlets. The goal is to identify a phenomenon and understand how people experience this phenomenon, with the intention of finding any similarities between the experiences of these individuals. This helps in the understanding of the essence of the phenomenon and the impact that this phenomenon has on people (Starks $\&$ Trinidad, 2007). This method is unique in that the focus is on the descriptions given by participants and not on researcher interpretations (Creswell, 1997, p.60). In order to ensure that the conclusions are truly a result of the participant's experiences, the researcher must bracket or keep personal experiences as separate from the study as possible, as noted above. Deportation of a family member is the phenomenon under study and the focus is on the individual's experience in regards to this phenomenon. The researchers read the transcripts and went through the process of horizonalization of the data. Horizonalization involves identifying significant statements or quotes that provided insight into participant experiences of deportation. These statements were then categorized into themes. Finally, clusters of meaning, or overall theme categories, were formed (Moustakas, 1994).

\section{Results}

Five themes of participants' experiences after deportation emerged from the interviews: 1) Lifestyle changes and adjustments, 2) Social support, 3) Impact on family unit, 4) Impact on individual family members, and 5) Solutions to family separation. Each theme is described below and examples from participant transcripts are provided.

\section{Theme 1: Lifestyle Changes and Adjustments}

Participants shared that after their family member was detained and deported they had to make many adjustments in their lives. The most common changes were changes in the roles that each family member played, including the adoption of new responsibilities. For example, Carmen shared that while some of her children helped more around the house, her oldest daughter began contributing financially:

"Mi hija la mayor, pues ella no ayuda mucho en la casa porque esta estudiando y porque esta trabajando." ("My oldest daughter, she does not help much in the house because she is studying and because she is working.")

In Jose's case, he had to take over the father's landscaping business:

"when that happened it was like responsibility was thrown at me out of nowhere... I wasn't prepared for it, but ...I learned a lot from it, I put everything in excel files, I called everybody... from that point I keep trying to keep the business alive and I'm learning everyday from it."

Families also had to change their routines in order to cover the family needs or to dedicate more time to their family. If the individual that was deported was the main financial provider, then remaining family members had to work more hours to survive financially, often meaning that they spent less time at home. In other cases, such as Rebecca's, she wanted to ensure that her family felt united so she worked less to take more time to be with her family.

Yo tenia miedo de que mi familia se fuera a desunir entonces me enfoque mas en tratar de unirlos de que no nos separáramos como familia mas que en lo económico por eso económicamente estábamos muy mal. [I was afraid that my family would separate, so I focused more on trying to unite them, that we wouldn't separate as a family, more than on the economic, that is why economically we were doing very bad.] 
Other adjustments were also made to prevent further damage (emotional or situational) and to ensure that the family remained unified. For example, precautions were taken to avoid other family members being deported or in a case where the deportee returned, to avoid re-deportation. For example, in Julio's case they took precautions after his mother returned to avoid re-deportation:

No queremos que regrese al trabajo. [We don't want her to return to work.]

\section{Theme 2: Impact on Family Unit}

Families overall felt fear or worry for the deported member or worried that immigration officers would return. Families not only made changes in their lives, but were emotionally impacted as well. For example, Carmen explained how upset she felt after the deportation:

De un momento a otro no estaba, yo no les quería explicar que estaba pasando porque yo misma no lo entendía, no podía hablar no podía decir, no quería llorar delante de ellas. [From one moment to the next he wasn't here, I didn't want to explain what was going on because I did not understand it. I couldn't talk, I couldn't say, I didn't want to cry in front of them.]

Jose shared that he was scared that immigration would deport him as well, which eventually led to the family moving away:

I told my mom "let's move, let's move" and she wasn't as scared as me that they were going to come back but I eventually convinced her you know, that they were going to come back for us, that they knew that we lived here.

Participants also mentioned that there was also an overall feeling of confusion and sadness or depression. Carmen explains the difficulties they had as a family in processing the deportation:

No hemos podido hablarlo abiertamente como familia, sentimos y eso pero sabemos que ahi esta todo pero así no le hamos hablado bien cómo nos esta afectando aunque cada quien nos conocemos y sabemos que nos afecta a todos de diferente manera y a diferente grado pero no nos hemos dado la oportunidad. [And we haven't been able to talk about it openly as a family, we feel but we know that all of it is there, but we haven't talked about it well how it's affecting us even though we each know each other and we know that it affects us all in different manner and to a different degree, but we haven't given ourselves the opportunity.]

The family unit was often also affected economi- cally as they lost a big source of income if the family member was a parent, more specifically the father. If the father was the one being deported, individuals reported that they would be taken advantage of by people they worked for or people they hired (e.g. mechanic or construction worker) because those individuals knew that the "man of the house" was absent and that the spouse did not know the "business." For example, Carmen shared how she was taken advantage of by a man who she hired to fix her house but ended up taking her money and leaving the work half-done:

También sufrimos porque las personas no tienen una ética profesional nada mas miran que no que no sabes tu de las cosas...o piensan que uno no se va a dar cuenta y no te hacen el trabajo que te deben de hacer se dedican a robarte, en vez de ayudarte. [We also suffered because people do not have professional ethics. They just notice that you don't know about things, or they think that you won't notice and they don't do the job that they had to do. They steal from you instead of helping you.]

Jose shared how his father's client had them work more than necessary:

I tried to keep it going [dad's business landscaping project] and everything but after like 2 or 3 days, it was like the client was making me do things, repeat things, like she was kind of abusing me and then after that I discussed [it] with my mom, and she said 'let's go talk to them right now, let's just leave it as it is and see what kind of money they give us for what we have done so far.

\section{Theme 3: Impact on Individual Family Members}

The overall emotion that all family members felt was that of sadness, however each individual family member appeared to have reacted differently. It appears that reactions among participants was somewhat determined by age and environmental factors or stressors present at the time. In general, children appeared to exhibit more physical symptoms, while older individuals reacted with anger or felt stressed.

For example, Julio was enrolled in a university during the school year and when his mother was deported he was on his summer break. Although he reported feeling upset about the deportation, he implied that had he been in school, dealing with homework and other responsibilities, it would have been emotionally harder for him to deal with the situation:

Por eso a lo mejor no fue tan difícil como si haya estado en la escuela porque emocionalmente pues si me vine abajo. [Perhaps that is why it was not as difficult as if I had been in school because emotionally I did feel down.] 
In Jose's case his response was that of anger on top of feeling sad.: "Afterwards I think I was more angry, but at that point it was more sad and emotional."

Different participants described feeling hurt, having fear, seeing the event as traumatic, feeling confused as to what was going on, and feeling frustrated at not being able to do anything. Karla shared that despite experiencing the deportation process over 30 years ago, she still remembers various negative emotions that came with it:

Fue una, una experiencia muy desagradable, de impotencia, de dolor de, pues de que mas podría ser, sentimientos que a veces no podemos expresar verdad, de miedo de temor, que va a pasar? [It was a very disagreeable experience, of incapacity, of pain, of feelings that sometimes we can't express, of fear, of what's going to happen?].

Carmen shared how after the deportation her son withdrew from his friends and other social activities.

Mi hijo le afecto psicológicamente. El era muy activo, también deportista. Salía mucho con sus amigos, pero me he dado cuenta que ya casi no sale con sus amigos. Se retiro mucho de sus amigos. [My son was affected psychologically. He was very active, he was also into sports. He would go out with his friends a lot, but I have noticed that he doesn't go out with his friends as much. $\mathrm{He}$ withdrew a lot from his friends.]

Carmen also shared that her younger daughter became sick and doctors were not sure what illness she had, implying that her daughter was somatisizing her emotions.

La mas chiquita ella se enfermo no encontraban el por que estaba enferma e incluso le recetaron mucha le recetaron mucha penicilina que hasta ahora la penicilina ya no le hace efectos se volvió inmune a la penicilina. [The youngest one [daughter] got ill. They couldn't find out why she was ill, and they even prescribed her a lot of penicillin, a lot, that even today penicillin no longer has an effect. She became immune to penicillin.]

\section{Theme 4: Solutions to Family Separation}

As soon as the family member was detained family members began trying to find ways to avoid deportation of that family member. Julio stated:

Ese día tratamos de contactar a un abogado, yo le llame a unos, 2 de mis profesores ... y tratamos de ver que era lo mejor la mejor decisión para hacer, o cuales eran nuestras opciones. [That day (of mother's detention) we tried to contact a lawyer. I called two of my professors and we tried to see what was best, the best decision to make or what our options were.]

Once the individual was deported, they thought about possible solutions to keeping the family together. All appeared to have considered having the individual come back illegally, but not all of them decided to do so. Other options that were often considered were leaving the U.S. to join the individual in their home country or simply maintaining frequent communication until a legal solution was found. Carmen shared that in order to keep her daughters in contact with the father, the daughters traveled to visit him, but also shared the difficulties in being able to do so:

Hasta hace un año que pudimos ya arreglar todos los papeles, el pasaporte, todo, permisos para que viajaran y pues económicamente también no estábamos bien porque pues la entrada de dinero ya se habia ido, entonces pues tuvimos que reunir dinero para este que ellas pudieran viajar. [Until one year ago we were able to fix all the paperwork, the passport, everything, permits for them (daughters) to travel and economically we weren't well either because the money income was gone (father deported), so we had to save money so that they could travel.]

Carmen also shared that they do plan to have her husband come back legally if they can obtain permanent residency through her daughter:

La decisión de que nos quedáramos hasta mirar que pasa con nuestro caso porque mi hija, ella es la ciudadana y el próximo ano cumple los 21 anos a partir de que ella cumpla los 21 años y veamos que podamos hacer vamos a tomar la decisión de quedarnos. [The decision (was) to stay until we know what happened with our case because my daughter, she is the citizen and next year she turns 21. After she turns 21 and we see what we can do, we are making the decision to stay."]

\section{Theme 5: Social Support}

Individuals reported that they received emotional support from friends and family. As Carmen stated: Pues tratamos de darnos ánimos uno con otro pero pues es dificil, bien dificil que es. [We tried to cheer each other but it's difficult, very difficult.] They mentioned receiving instrumental support such as staying at someone else's house or having a friend or family take money to the individual while they were at the deportation center. They also received help from lawyers or friends who knew people who could help them. Thus, once the family member was deported, they might have received help in getting back to the country or 
in knowing where to go to from there. Additionally, it was interesting that all participants towards the end of the interview asked that their political opinions be expressed in this study. Participants expressed a desire to receive more support from the U.S. government through immigrant reform and more flexible policies that would allow families to be separated for less time. Participants also asked for the government to be more considerate when deporting individuals who had been good citizens in this country by having policies that facilitate the process of obtaining legal residence in the U.S., especially for individuals who have U.S. born and raised children.

\section{Discussion}

Deportation of undocumented immigrants from the U.S. is a subject that has been scarcely researched despite the fact that much attention has been given in politics and the media to immigration issues. The current study contributes to the literature by exploring how individuals who had a family member deported were affected. A total of five themes were found that highlight the main characteristics of the deportation phenomenon. The participants shared that after having a family member detained and deported, they had strong negative feelings that lasted for years or until the person was able to return. Sadness and worry were most common. Other impacts on lifestyle and behavior were also noted. Most commonly, the role that the deported family member fulfilled within the family as financial provider or provider of support determined how the remaining family members would be impacted due to what new roles they would have to fill. These findings were consistent with a previous study on immigration with recent immigrant youth from Central America, China, Haiti, Mexico, and the Dominican Republic (Suarez-Orozco, Todorova, \& Louie, 2002), showing that children who were separated from their parents reported more depressive symptoms than those who were not separated during the immigration process. This study demonstrates how family separation can have an impact on children's well-being. Yet, it is important to differentiate between deportation and immigration, since deportation is perceived as a negative unforeseen event or situation, whereas immigration is a circumstance that families often seek in order to improve their current situation. Thus, the negative impact of deportation may be even greater for children.

This study highlighted that the type or level of impact of deportation on families is somewhat dependent on the role that needs to be filled after the family member is no longer present. Thus, the more roles that the deported individual fulfilled, the more areas of need the family will have. For example, in Carmen's case, she found herself needing to provide financially for her family in addition to going through the loss herself and needing to provide emotional support to other family members.

Other studies have also concluded that individuals who are undocumented experience the stressor of knowing that they are vulnerable to deportation, thus creating greater risk for other mental and health issues. Additionally, they are less likely to seek any type of help or services for fear of deportation (Heyman, Nuñez, \& Talavera, 2009). Moreover, immigrants who are concerned about deportation can experience poor subjective health status and negative emotional stress, which can also be linked to their limited financial and employment opportunities (Cavazos-Rehg, Zayas, \& Spitznagel, 2007). Given that participants in this study had already experienced the deportation of a family member, it is not surprising that their fear of having someone else in their family deported was greater than before, or in cases where the individual returned, that they feared them being deported again. As mentioned before, this fear led them to take additional precautions, which sometimes resulted in changing their lifestyles such as by avoiding work or changing residences.

Despite the negative impacts that deportation of a family member had on individuals, the concept of familismo stands out as strength. A priority for families soon after the deportation appeared to be providing support to other family members and ensuring that the family remained cohesive despite the distance. For example, other family members might serve as motivators so that a mother would avoid feeling depressed in order to emotionally support her children. Still others took over more responsibilities in order to provide for the family. In a few cases, the participants were also able to rely on extended family members for support, including being able to stay at their houses or receiving financial support from them. This overall finding of familismo as a source of strength is consistent with extant literature (Clauss-Ehlers \& Wibrowski, 2007; Carranza, 2007; Smokowski \& Bacallao 2006).

A second goal that this study had was to identify any resource needs that this population might have. Based on the interviews, it was apparent that some of these participants were unsure of their rights or of the deportation process. Previous literature has indicated that Latino/as do not use social services as much as other groups, especially undocumented Latino/as (Heyman, Nuñez, \& Talavera, 2009; Macnaughton, 2008; Nandi, et al., 2008). This was the case for some participants, but not all. In the case of Julio, his family contacted a lawyer after his mother was detained. This lawyer was recommended by an acquaintance who was familiar with the deportation process. Both of these 
examples emphasize the importance of social support and connection within this community, but point to a lack of general information. It appears that increasing the output of information on issues or programs concerning legal rights, the deportation process, or other information that could be beneficial to this population would be helpful. Additionally, encouraging and possibly facilitating social connections to other community members could aid in augmenting immigrants' social support network and ensure that they have more opportunities for being well informed. Providing more information on the safety of accepting certain services may reduce fears of accepting any help.

\section{Limitations and Future Directions}

This qualitative study was intended to provide information on families who were affected by the deportation of a family member. Previous studies have pointed out differences between undocumented and documented Latino/as, yet not much information has been available on what happens after an individual is confronted with having someone they care about be deported. Despite the valuable information that this study provided it had several limitations. Most of the participants were originally from Mexico, and it is likely that Latino/a individuals from other Central or South American countries might face other challenges or stressors due to geographic distances between the U.S. and the country to which their loved one was deported. For example, if children are to travel to visit their parent who was deported, it might be harder to fund a trip to South America than to Mexico. We were not able to capture other possible issues that characterize or are directly linked to experiencing deportation for individuals from other countries.

Another limitation was that only one member from each family was interviewed, and thus it could not be confirmed that the other family members truly felt as the participants described them. The responses provided in this study are framed from that participant's perspective, as a result we cannot have an accurate picture of how other family members were impacted. A future study could focus on interviewing several family members within a family in order to obtain a clearer picture on how the family was impacted as a whole and from different perspectives. It would also be valuable to do a study focusing on the impact that a parent's deportation has on children, given that it might be more plausible that professionals will encounter children in this circumstance than an adult whose family member was deported. If interventions are to be implemented, then obtaining information on programs or types of aid that appear most helpful to families who find themselves in this situation would be beneficial as well.

\section{Implications for Mental Health Work}

Overall, the findings from this study indicate that the deportation phenomenon is one that brings many changes and difficulties to affected families. The impact it has on families can vary based on their current financial situation, the number of remaining family members, the ages of the family members, and their plans to be reunited. Therefore, when working with individuals who had a family member deported mental health professionals should be sensitive to that individual's specific situation and be aware that they might need additional services.

Additionally, it is important for service providers to be aware of the circumstances that children of deported individuals might face and to prepare for working with families in this situation. For example, if the child is not obtaining as much attention as before due to the absence of a parent, more resource information, aid and/or recommendations might be needed from the school (for example, an after school program). In the case of Carmen, after her husband was deported she had financial difficulties and after receiving information from friends, she decided to obtain financial aid from the government. It would be our hope as well that this information could also help inform immigration policies given that current laws have had such a negative impact on many Latino/a families in the U.S.

\section{References}

Baker, S. G. (1996). Homelessness and the Latino paradox. In J. Baumohl (Ed.), Homelessness in America (pp. 132-140). Phoenix, AR: Oryx.

Bender, D. \& Castro, D. (2000). Explaining the birth weight paradox: Latina immigrants' perceptions of resilience and risk. Journal of Immigrant Health, 2(3), 155-173.

Benjamin, G.A.H., Kahn, M.W., \& Sales, B.D. (1984). Developmental differences in Infants and policy on undocumented Mexican American parents. Hispanic Journal of Behavioral Sciences, 6, 145-160.

Buckler, K., Swatt, M.L., \& Salinas, P. (2009). Public views of illegal migration policy and control strategies: A test of the core hypotheses. Journal of Criminal Justice, 37, 317-327.

Caplan, S. (2007). Latinos, acculturation, and acculturative stress: A dimensional concept analysis. Policy, Politics, \& Nursing Practice, 8, 93-106.

Clauss-Ehlers, C.S. \& Wibrowski, C.R. (2007) Building Educational Resilience and Social Support: The Effects of the Educational Opportunity Fund Program Among First- and Second-Generation College Students. Journal of College Student Development, 48(5), 574-584.

Carranza, M.E. (2007). Building resilience and resistance against racism and discrimination among Salvadorian female youth in Canada. Child and Family Social Work, 12, 390-398.

Cavazos-Rehg, P.A., Zayas, L.H., \& Spitznagel, E.L. (2007). Legal status, emotional well-being and subjective health status of Latino immigrants. Journal of the National Medical Association, 99(10), 1126-1131. 
Creswell, J. W. (1997). Qualitative inquiry and research design: Choosing among five traditions. Thousand Oaks, CA: Sage.

De Minzi, M.C.R. (2009). Influencia del modelado de los padres sobre el desarrollo del razonamiento prosocial en los niños/ as. Interamerican Journal of Psychology, 43, 187-198.

Esparza, P. \& Sanchez, B. (2008). The role of attitudinal familism in academic outcomes: A study of Urban, Latino high school seniors. Cultural Diversity and Ethnic Minority Psychology, 14(3), 193-200.

Finch, B.K. \& Vega, W.A. (2003). Acculturation stress, social support, and self-rated health among Latinos in California. Journal of Immigrant Health, 5, 109-117.

Glaser B.G. \& Strauss A.L. (1967) The Discovery of Grounded Theory. Aldine: Chicago.

Heyman, J.M., Nuñez, G.G., \& Talavera, V. (2009). Healthcare access and barriers for unauthorized immigrants in El Paso County, Texas. Family \& Community Health, 32(1), 4-21.

Holleran, L.K. \& Jung, S. (2005). Acculturative Stress, Violence, and Resilience in the lives of Mexican-American Youth. Stress, Trauma, and Crisis, 8, 107-130.

Lara, M., Gamboa, C., Kahramanian, M.I., Morales, L. \& Bautista, D. (2005). Acculturation and Latino health in the United States: A review of the literature and its sociopolitical context. Annual Review of Public Health, 26, pp. 367-397.

Lee, Y. \& Ottati, V. (2002). Attitudes toward U.S. immigration policy: The roles of in-group-out-group bias, economic concern, and obedience to law. The Journal of Social Psychology, 142, 617-634

MacNaughton, N.S. (2008). Health disparities and health-seeking behavior among Latino men: A review of the literature. Journal of Transcultural Nursing, 19, 83-91.

Marshall, K.J., Urrutia-Rojas, X., Soto Mas, F., \& Coggin, C. (2005). Health status and access to health care of documented and undocumented immigrant Latino women. Health Care for Women International, 26, 916-936.

Moustakas, C. (1994). Phenomenological research methods. Thousand Oaks, CA: Sage.

Nandi, A., Galea, S., Lopez, G., Nandi, V., Strongarone, S., Ompad, D.C. (2008). Access to and use of health services among undocumented Mexican immigrants in a US urban area. American Journal of Public Health, 98, 2011-2020.

Ortega, A. N., Rosenheck, R., Alegria, M., \& Desai, R. A. (2000). Acculturation and lifetime risk of psychiatric and substance use disorders among Hispanics. Journal of Nervous and Mental Disease, 188, 736- 740.

Parra-Cardona, J.R. (2006). "Trabajando duro todos los días": Learning from the life experiences of Mexican-origin migrant families. Family Relations, 55, 361-375.

Patton, M. (1990). Qualitative evaluation and research methods. Sage Publications, Newbury Park, California.

Pew Hispanic Center (2008). Statistical Portrait of Hispanics in the United States, 2008. Retrieved from http://pewhispanic.org/ factsheets/factsheet.php?FactsheetID $=58$

Smokowski, P.R. \& Bacallao, M.L. (2006). Acculturation, internalizing mental health symptoms, and self-esteem: Cultural experiences of Latino Adolescents in North Carolina. Child Psychiatry \& Human Development, 37, 273-292.

Starks, H. \& Trinidad, S.B. (2007). Choose your method: A comparison of phenomenology, discourse analysis and grounded theory. Qualitative Health Research, 17, 1372-1380.

Suarez-Orozco, C., Todorova, I.L.G., \& Louie, J. (2002). Making up for lost time: The experience of separation and reunification among immigrant families. Family Process, 41(4), 625643.

Sullivan, M.M. \& Rehm, R. (2005). Mental health of undocumented Mexican immigrants: A review of the literature. Advances in Nursing Science, 28, 240-251.
The White House (2010, August 12). Statement by the president on the passage of the Southwest border security bill. Retrieved from http://www.whitehouse.gov/the-press-office/2010/08/12/statement- president-passage-southwestborder-security-bill

Received 03/13/2012 Accepted 02/07/2013

Nelly Gonzalez. University of California, Santa Barbara

Melissa L. Morgan Consoli. University of California, Santa Barbara 